\title{
Správa z konferencie ALMS Conference Berlin 2019: ,Queering Memory - Archives - Arts - Audiences'
}

Michal Mako

\section{Report from the ALMS Conference 2019 in Berlin: "Queering Memory - Arts - Archives - Audiences"}

Abstract: The conference, organised by the Berlin-based Institute of Magnus Hirschfeld, was focused on the position of queer memory in the contemporary memory institutions such as museums, archives and specialized collections as well as the expression of queer-related topics in art.

Keywords: conference, queer, queer history, memory, archive, memory institutions

Nemecká vedecká spoločnost’ „MagnusHirschfeld-Gesellschaft" zorganizovala $\mathrm{v}$ spolupráci $\mathrm{s}$ d’alšími inštitúciami ${ }^{1}$ v dňoch 27. až 29. júna 2019 už šiestu zo série medzinárodných konferencií $\mathrm{ALMS}^{2}$, tentokrát s podtitulom "Queering memory".

Od roku 2006, kedy sa uskutočnila prvá konferencia zo série ALMS v americkom Minneapolise, sa nezmenila hlavná misia týchto tematických konferencií. Nepretržite sa tak zameriavajú na verejné, súkromné, akademické a miestne organizácie, ktoré zbierajú, spracovávajú a uchovávajú materiály všetkého druhu, zaznamenávajúce zážitky či skúsenosti queer ${ }^{3}$ komunity, pričom dbajú na zabezpečenie kontinuity dokumentovania a zdiel'ania ich histórie.

Konferencia ALMS 2019 v Berlíne získala vd’aka svojmu miestu a dátumu konania silnú historickú symbolickú hodnotu. Konala sa presne 100 rokov po založení nemeckého "Institut für Sexualwissenschaft" ktorý sa stal historicky prvým známym archívom, knižnicou a múzeom queer histórie na svete. A to bol ešte založený na rovnakom mieste, kde dnes stojí „Haus der Kulturen der Welt" v samotnom srdci Berlína, na mieste usporiadania konferencie ALMS 2019.

Tohtoročná konferencia ALMS sa zamerala na problematiku "Queering memory".
Pojmom "queering" sa v kontexte historickej vedy označuje nástroj takej historickej analýzy, prostredníctvom ktorej sa dekonštruuje tradičný bipolárny rodový (genderový), pohlavný a heteronormatívny (heterosexuálny) naratív dejín ludskej spoločnosti. Hlavným cielom sa tak stalo premýšllanie o tom, ako túto špecifickú historickú analýzu používat' v kontexte súčasných politických, spoločenských a kultúrnych podmienok. Ako zviditel'nit' rôznorodú, diverzifikovanú queer minulost' $\mathrm{v}$ týchto digitalizovaných časoch? Účastníci konferencie premýšlali a diskutovali o (ne)objavenom potenciáli pre generovanie a rozširovanie publika queer histórie, queer archívov, knižníc, múzeí či špeciálnych zbierok. Osobitnú pozornost venovali role umenia a umeleckých intervencií.

Každý konferenčný deň bol rozdelený do troch prednáškových blokov. Výstupy účastníkov prebiehali simultánne v šiestich miestnostiach. Počas jednotlivých prestávok mali zúčastnení možnost' pozriet’ si niekol'ko rozmanitých dokumentárnych a umeleckých filmov s queer tematikou. ${ }^{5}$ Aj vo večerných hodinách obohatili atmosféru konferencie premietania filmov a dokonca aj jedna divadelná hra. ${ }^{6}$ Počas celej konferencie boli na viacerých miestach budovy umiestnené umelecké inštalácie ${ }^{7}$ a prezentačné stánky mnohých
1 FFBIZ (das feministische Archiv); Forschungsstelle Kulturgeschichte der Sexualität, HumboldtUniversität zu Berlin; Initiative Queer Nations; Lili-ElbeArchiv; Schwules Museum; Spinnboden (Lesbenarchiv und Bibliothek Berlin).

2 ALMS - Archives, Libraries, Museums and Special Collections (archívy, knižnice, múzeá a špeciálne zbierky). 3 Zastrešujúci výraz pre zoskupenie rôznorodých sexuálnych, pohlavných či rodových menšín. Termín reprezentuje osoby s takou sexuálnou orientáciou, rodovou identitou (resp. rodovým vyjadrením) a pohlavím, ktoré vybočujú $z$ tradičnej heteronormatívnej bipolárnej rodovej a pohlavnej spoločnosti.

$\mathbf{4}$ "Sexuologický inštitút”, resp. "Inštitút pre výskum sexuality".

5 Napr. Carne (Flesh). Juliana Streva, Brazilia/Nemecko, 2019; The Archivettes. Megan Rossman, USA, 2018; We Are Here: LesBiTrans in China. Jing Zhao - Shi Tou, Č́na, 2015; Katha Vachak (Storyteller).

Deepak Srinivasan, India, 2019 a dalšie.

6 The Einstein of Sex. Livingstones Kabinet, Dánsko.

Mgr. Michal Mako Historický ústav Filozofická fakulta Masarykovy univerzity Brno mizuumako@gmail.com 
7 Napr. Berlin-Yogyakarta: From Hitler's terror against homosexuals to human rights today. Katarzyna Remin, Pol'sko; Magnus Hirschfeld's french exile guestbook - introduction to an exhibit. Hans Bergemann Ralf Dose, Nemecko a iné.

8 Napr. GALA archives, Južná Afrika; Lambda Archives of San Diego, USA; LGBT Denmark, The LGBT Library (LGBT

Biblioteket), Dánsko; QRAB The Archives and Library of the Queer Movement,

Švédsko; Schwules Museum Berlin, Nemecko; STICHWORT. Archiv der Frauen - und Lesbenbewegung, Rakúsko; The ArQuives, Kanada; Centre audiovisuel Simone de Beauvoir, Francúzsko; Háttér Society, Madarsko.

9 Vel'mi výstižne najmä Jedrzej

Burszta v príspevku "How to talk about homosexuality, if it didn't exist? Studying

Queer Narratives about 1970s

Poland.", Karel Radziszewski

v príspevku "Queer Archives Institute: Institution as an Art Practice.", Magdalena

Staroszczyk v príspevku "No one talked about it: The

Paradox of Lesbian Identity in pre-1989 Poland and Absence in Archives.", či napokon

Tomasz Basiuk v príspevku

"The Queer 1970s and Early

1980s in Poland as a Proto-

Political Era: Evidence from Emerging Archives."

10 Krzysztof Zablocki v prispe$v k u$ "The Archives Collection of the Lambda Warszawa Association, the Oldest Polish LGBTQ Organization."

11 V príspevku "The Art of Queer Memory: The Artistic and Curatorial Strategies to Commemorate LGBTQ Past in Eastern Europe."

12 V príspevku "Fundacja Q: Poland's Virtual LGBTQ+ Museum and Contemporary Queer Archives."

13 V príspevku "Photo Series Representing the Private Life and Civil Activity of LGBTQ People in Hungary."

14 Orig. "Háttér Társaság”. 15 Péter Hanzli a Sándor Nagy vystúpili spoločne $v$ príspevku „Háttér Archives: The Oldest East European LGBT+ Archive organizácií z celého sveta venujúcich sa queer dejinám. ${ }^{8}$ Účastníci mohli okrem iného dvakrát absolvovat' tematické organizované vychádzky, tzv. „queer walking tours" po Berlíne.

$\mathrm{Na}$ trojdňovej konferencii sa stretlo viac ako 350 účastníkov z viac než 40 krajín sveta. Zastúpené boli všetky svetové obývané kontinenty. Stredoeurópsky geografický priestor reprezentovalo niekol'ko účastníkov. Za Pol'sko vystúpili Jedrzej Burszta, Karel Radziszewski, Krzysztof Zablocki, Magdalena Staroszczyk, Pawel Leszkowicz, Tomasz Basiuk a Karolina Ufa. Autori vo svojich príspevkoch kriticky poukázali najmä na absenciu a následne súvisiacu nutnost' tvorby a ochrany rôznorodých queer archívov v pol'skom prostredí. ${ }^{9}$ Prezentovali doterajšie snahy pôvodných pol'ských organizácií budujúcich queer archív, ich problémy a smerovanie $\mathrm{k}$ súčasnosti. ${ }^{10}$ Historik umenia Pawel Leszkowicz vyzdvihol queer umenie ako obrovský zdroj dokumentácie, rekonštrukcie a zdiel'ania queer minulosti najmä v Centrálnej a Východnej Európe 21. storočia. ${ }^{11}$ Aktivistka Karolina Ufa odprezentovala projekt pol'ského virtuálneho queer múzea, ktoré má za ciel' dokumentovat’ životné príbehy neheterosexuálnych l'udí z najnovších pol'ských dejín. V spolupráci so spoločnostou Google otvorili virtuálne múzeum, ktoré v súčasnosti obsahuje zbierku viac ako 1200 stránok naskenovaných rozličných časopisov a novín, 100 plagátov, 50 rôznorodých druhov fotografií, 300 až 400 letákov, brožúrok a d’alších jednotlivých papierových výstrižkov. Súčastou virtuálneho múzea majú byt’ v blízkej budúcnosti takisto zvukové a filmové nahrávky. ${ }^{12}$

Z Mad'arska a Slovenska pricestovali Judit Szabó, Judit Takács, Péter Hanzli, Sándor Nagy a Zoltán Csehy. Ked’že v mad’arskom prostredí v súčasnosti existujú fungujúce queer archívy, účastníci sa zrejme preto zamerali skôr na ich doterajšiu prácu a prezentáciu v tejto oblasti. Judit Szabó predstavila vlastný projekt fotografovania mad’arskej queer komunity v súkromnom ako aj verejnom živote a možnosti použitia týchto dokumentov k zvel'ad'ovaniu zbierok queer archívov či múzeí. ${ }^{13}$ Péter Hanzli a Sándor Nagy spoločne prezentovali doterajšie fungovanie „Háttér Society"14 v Budapešti a jej špecifickú realizáciu mad’arského queer archívu a knižnice s uvedením plánov do budúcnosti, napr. zavedenia elektronickej databázy. ${ }^{15}$ Judit Takács popísala vlastný archívny historický výskum dekriminalizácie homosexuality v Mad'arsku. ${ }^{16}$ Mad'arskoslovenský autor, básnik a prekladatel' Zoltán Csehy zdôraznil význam a prínos antologickej LGBTIQ ${ }^{17}$ poézie, ktorá môže byt’ špeciálnym zdrojom queer minulosti a následného použitia $\mathrm{v}$ archívoch a múzeách nielen v Mad’arsku. ${ }^{18}$

$\mathrm{Z}$ rakúskeho prostredia sa zúčastnili napr. Andreas Brunner, Klaus Mueller a Christiane Erharter. Európa niekdajšej západnej strany železnej opony je v prístupe ku queer minulosti vo všeobecnosti výrazne zhovievavejšia. Dôkazom je zretel'ne vyššie zastúpenie špecializovaných pracovísk a osôb, ktoré sa venujú queer histórii. Táto odlišnost’ bola zrejmá aj na samotnej konferencii ALMS 2019. V niektorých príspevkoch bola citel'ná dlhodobá cesta vývoja uchovávania, spracovávania a prezentovania queer minulosti. Mali sme dojem, že sa problémy s tým späté posunuli $\mathrm{v}$ západnom svete už o istý mentálny, ale aj samotný „obyčajný“ praktický stupeň vyššie. Ako príklad poslúžili príspevky rakúskych kolegov.

Rakúsky historik Andreas Brunner, spoločne s nemeckou kolegyňou Carinou Klugbauer a kolegom Hannes Hacke, prezentovali svoj odvážny projekt „QueerSearch". V ňom si kladú za ciel' založenie online portálu pre LGBTIQ archív nemecky hovoriacich krajín, ktorý by umožnil vyhl'adávanie prostredníctvom vel'kého množstva katalógov a databáz spolupracujúcich cez desiatky spriatelených organizácií. Tie by mali svoje databázy prepojit' do jedného celku. Chcú tak úplne zjednodušit' vyhl'adávanie a prístupnost' queer pamäte, zvýšit' viditel'nost' jej rôznorodých zbierok a získat' preň omnoho širšie publikum. Ide teda o vel'ký 
medzinárodný projekt, ktorý chce digitalizovat' a prepájat' už rozsiahlo prebádanú queer minulost. ${ }^{19}$

Klaus Mueller sa zase kriticky vyjadroval k súčasným múzejným expozíciám a ich klasickému, tradičnému interpretovaniu minulosti. Autor vo všeobecnosti kritizoval múzeá, ktoré sa podla neho málo zaoberajú spoločenskou inklúziou. Poukázal na to, že LGBTIQ návštevníci múzeí sú tak často $\mathrm{v}$ podstate neobsiahnutou, "neviditelnou“ skupinou obyvatel'stva minulosti. ${ }^{20}$

Christiane Erharter predstavila medzinárodný výber umelcov, ktorých prezentovaná tvorba a prax súviseli s queer (najmä gay a lesbickou) minulostou niekdajších socialistických krajín Európy. Vo svojom príspevku si kládla otázky: ako socializmus postihol sexuálne identity osôb? Ako vojna v Juhoslávii v 90 . rokoch 20 . storočia ovplyvnila queer identitu? Poukázala na rôznorodé umelecké vyjadrenia $\mathrm{z}$ rozličných geopolitických kontextov, ktoré vytvárali rámec queer životov a následne ich naratívov. Autorka tak predstavila umeleckú prax „rozprávania príbehov“ vo verejnom priestore z geopolitickej perspektívy. ${ }^{21}$

"Západní" autori sa zameriavajú skôr na rôznorodejšiu a širšiu kritiku muzeálnych a archívnych expozícií. Často poukazujú na nové perspektívy a stanovujú si nové rámce bádania a zdielania queer histórie vo verejnom priestore. Zatial čo autori „východného sveta" väčšinou bojujú o číre bádanie $v$ tejto oblasti, o jeho rozvoj, inštitucionálnu, materiálnu ako aj personálnu podporu.

$Z$ českého prostredia sa na konferencii aktívne zúčastnil Ladislav Zikmund-Lender. Vo svojom príspevku predstavil a popísal tvorbu a charakter niekolkých zbierok rôznorodých artefaktov, ktoré vytvorili gay muži počas 20. storočia. Autor sa zameral na politické a osobné motivácie, ktoré viedli k vytvoreniu týchto zbierok. Vo svojom vystúpení zároveň hladal odpoved' na metodickú otázku, ako sa istá špeciálna zbierka stáva "queer". Na pozadí tejto problematiky sa kriticky vyjadril k súčasnému zbieraniu, uchovávaniu a spracovávaniu podobných artefaktov, pričom poukázal na to, že súčasná (česká) inštitucionálna prax $\mathrm{v}$ podstate participuje na vymazávaní queer minulosti a pamäte. Išlo tak o podobný kritický prístup aký často vidíme $\mathrm{v}$ zahraničnom prostredí na západ od hraníc Čiech a Slovenska. Ako protiváhu tradičného archívneho a muzeálneho prístupu $\mathrm{v}$ českej spoločnosti odprezentoval pražský spolok "Společnost pro queer pamět", v ktorom aktuálne figuruje ako člen výboru. ${ }^{22}$

Tri rozmanité a inšpiratívne konferenčné dni ukončila záverečná debata, ${ }^{23}$ na ktorej vystúpili významní svetoví odborníci a odborníčky v tematike queer dejín - Pia Laskar ${ }^{24}$, Leonardo Arouca Porfiro da Silva ${ }^{25}$, Jonathan D. Katz ${ }^{26}$, Judit Takács ${ }^{27}$, Aaron Devor ${ }^{28}$ a Katerina Suverina ${ }^{29}$. Výber diskutujúcich symbolicky reprezentoval rôznorodé oblasti sveta a ich inštitucionálne kontexty (východ, západ, sever a juh). Toto podujatie sa stalo dôkladnou reflexiou uplynulých dní konferencie. Debatéri sa zamerali na politické aspekty a výzvy, ktorým nečelia iba queer archívy, knižnice, múzeá a špeciálne zbierky, ale takisto aj samotní nositelia queer pamäte, teda queer osoby a ich životy. Zdôrazňovali nutnosṫ globálnej solidarity v budúcnosti.

Konferencia ALMS 2019 sa stala priatelským, menej formálnym a viac otvoreným miestom stretnutia ohromného množstva archivárov, múzejníkov, historikov, aktivistov, akademikov či bádatel'ov z celého sveta. Umožnila priebeh bohatej kritickej diskusie, počas ktorej mohli jej účastníci nazbierat' množstvo nových podnetov $\mathrm{k}$ ich výskumnej činnosti a zároveň zdiel'at vlastné praktické problémy s dokumentáciou queer dejín, ktoré neustále musia „bojovat" o svoje miesto na slnku“. and LGBT History Month in Hungary."

16 V príspevku

„Decriminalisation of Homosexuality in Hungary in the Light of Recently Discovered Archive Records." 17 Skr. lesbickej, gay, bisexuáInej, transgenderovej, intersexuálnej a queer.

18 Mad'arsko-slovenský akademik, básnik a prekladatel' vystúpil s príspevkom „Collecting Poems: LGBTIQ Anthologies as Archives of Taste and Self-Representation." $19 \mathrm{~V}$ príspevku "QueerSearch: A Joint Online Portal for LGBTIQ* Archives in the German-speaking Countries." 20 V príspevku "The Invisible Visitor: Museums and the LGBTI Community."

21 V príspevku "Queer Stories: Artists Working with Queer Histories/Herstories/Stories in Former Socialist Countries." 22 V príspevku "The Will to Preserve: Is Collecting Queer?". 23 Evening podium "Queering memory, defending the future" $v$ sobotu 29. 6. 2019 večer od 19:00. 24 Swedish National Historical Museums, Štokholm, Švédsko. 25 Museum of Sexual Diversity, São Paulo, Brazília. 26 Harvey Milk Institute, San Francisco, USA a hostujúci profesor na University of Pennsylvania, USA.

27 Centre for Social Sciences, Hungarian Academy of Sciences, Budapešt', Madarsko. 28 Transgender Archives \& Chair in Transgender Studies, University of Victoria, Kanada. 29 Public History Laboratory \& Garage Museum of Contemporary Art, Moskva, Rusko. 